BISSET, K. A. (1951). J. gen. Microbiol. 5, 155-158.

\title{
The Development of the Surface Structures in Dividing Bacteria
}

\author{
By K. A. BISSET \\ Department of Bacteriology, University of Birmingham
}

SUMMARY: The cell wall of growing Gram-negative bacteria is formed mainly, or entirely, at one pole of the cell. At this point the cell wall is soft and transparent to the electron beam, and there is a concentration of stainable material in the underlying cell membrane. A similar 'growing point' occurs at the point of cell division. In dividing bacteria, the portion of the surface which bears the flagella is retained in its entirety by one daughter cell, the other daughter cell grows new flagella.

In the course of an investigation of the growth of bacterial flagella (Bisset \& Hale, 1951) it was observed that the flagella tended to develop at one pole of the cell in the process of germination from the microcyst stage. It was also observed that, in dividing cells of Salmonella typhi, one daughter cell was usually flagellated while the other was not. This phenomenon was further examined, and observations were made upon Proteus vulgaris and Pseudomonas fluorescens.

\section{METHODS}

Electron microscopy and silver impregnation stains for photomicrography were used, exactly as in the foregoing study (Bisset \& Hale, 1951).

\section{OBSERVATIONS}

Preparations were made of young cultures from 2 to $24 \mathrm{hr}$. old. When the original inoculum consisted of non-flagellated microcysts (Bisset, 1950) cell division commenced shortly after germination and was active after 3 or $4 \mathrm{hr}$.

Salmonella typhi. Dividing cells first elongated considerably, and in this condition it was already apparent that almost all flagella were confined to onehalf of the cell (Pl. 1, figs. 1-3). When division was complete all the flagella remained on one daughter cell, the other being quite devoid of flagella or just commencing to produce them (Pl. 1, figs. 4, 5).

Proteus vulgaris. This bacterium divided in a similar manner, but there was a significant difference from the condition in Salm. typhi. The original flagella were retained upon one half of the growing cell, but new flagella began to develop upon the other half before division was completed. Thus in a bacterium which was on the point of division, or had just divided, one daughter cell usually had much longer flagella than the other (Pl. 2, figs. 6-9).

Growing points. The conclusion from these observations upon the behaviour of the flagella in dividing bacteria is that the cell wall and flagella-bearing structures are produced at one pole of the cell. This was borne out by the appearance of the cell wall in electron micrographs. Nearly always the pole distant from the flagella was soft and transparent in appearance. This can be 
seen in Salm. typhi (Pl. 1, figs. 2, 4), but is more obvious in Proteus (PI. 2, figs. 6,10$)$. When unfixed bacteria in this condition were lightly stained with an aqueous solution of Giemsa, one pole usually stained more intensely blue than the remainder of the organism (PI. 2, fig. 11). It may reasonably be assumed that this stainable material represents a concentration of secretory nucleic acids, which are responsible for the formation of the cell wall. A similar but rather less intense concentration occurred at the points of cell division, corresponding to the areas of secretion of cell-wall material indicated in a previous work (Bisset, 1948).

Pseudomonas fuorescens. The development of the flagella in this species was naturally somewhat different from the condition in the bacteria described above. The flagella are arranged in a tuft at one pole, but occasionally, in germinating microcysts, flagella may develop at the opposite pole before the initiation of cell division (Bisset \& Hale, 1951). This may possibly indicate that the polarity of growth of such cells is not yet established. More usually the flagella were confined to one pole until division was well advanced, or even completed (Pl. 3, figs. 12-16). The growing point of Ps. fluorescens was not noticeably transparent to the electron beam, perhaps because it was seldom far removed from the flagella-bearing condition, but the underlying, stainable, polar material was well seen (Pl. 3, fig. 17).

\section{DISCUSSION}

The foregoing observations provide additional evidence in support of the author's contention (Bisset, 1950) that the cell wall of bacteria is a dead structure, which does not grow but is secreted. It now appears that this secretion occurs mainly, if not exclusively, at two places, the point of division of a dividing cell (Bisset, 1948) and at one pole of a growing cell (Fig. 1). The new cell wall in

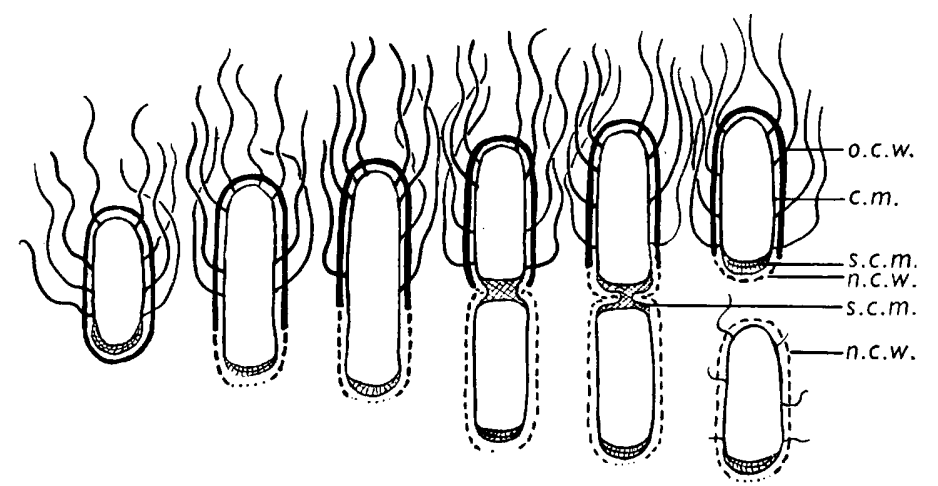

Fig. 1. The development of the cell wall in a bacterium with peritrichous flagella: o.c.w. old cell wall; c.m. cell membrane; s.c.m. secretory cell membrane; n.c.w. new cell wall.

process of formation is soft and transparent to the electron beam, presumably because it is thin. The concentration of stainable material in the growing point probably represents an area of secretory activity with a high proportion of 
Journal of General Microbiology, Vol. 5, No. 1
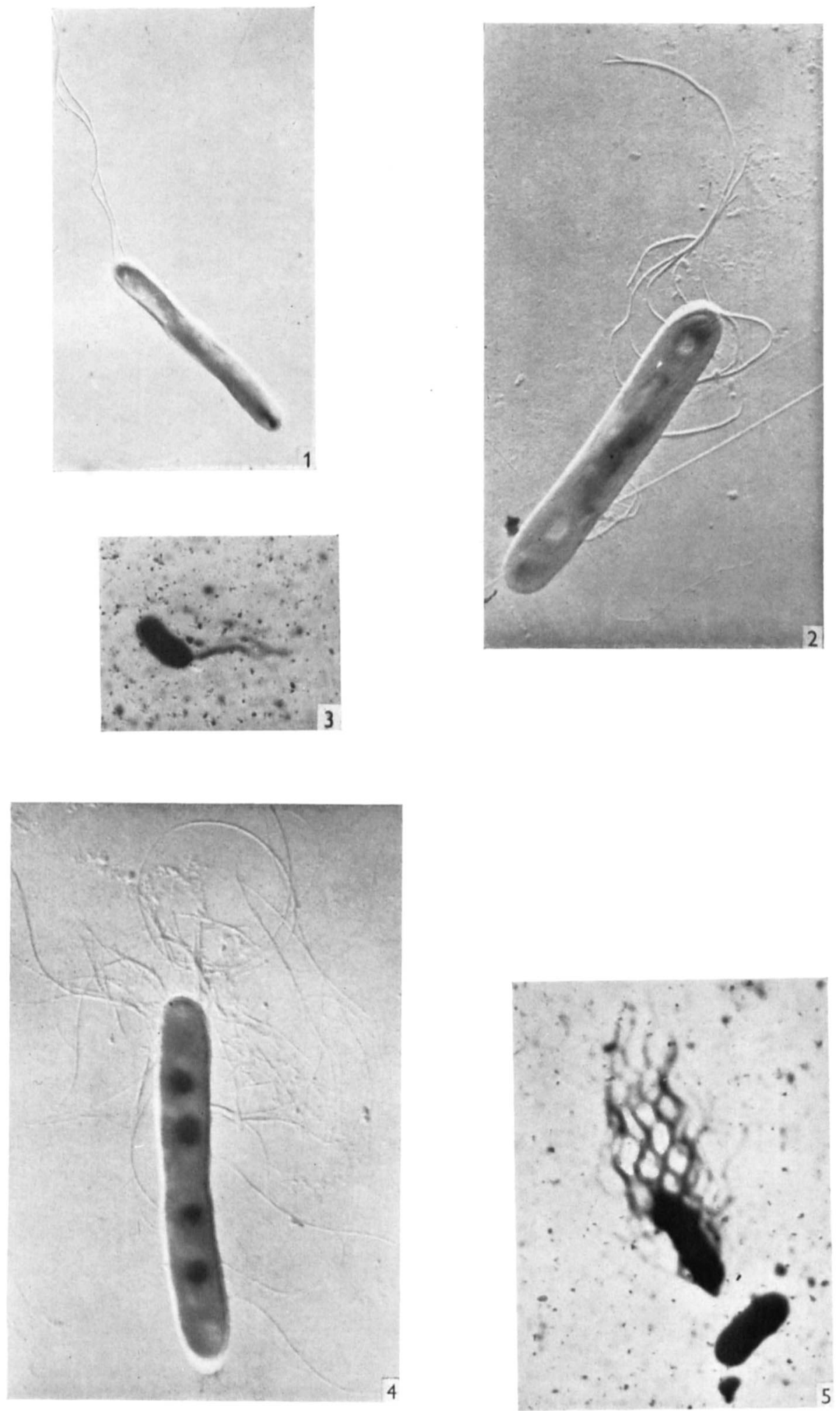

Figs. 1-5

K. A. Bisset-Surface structures in dividing BaCteria. Prate 1 
Journal of General Microbiology, Vol. 5, No. 1
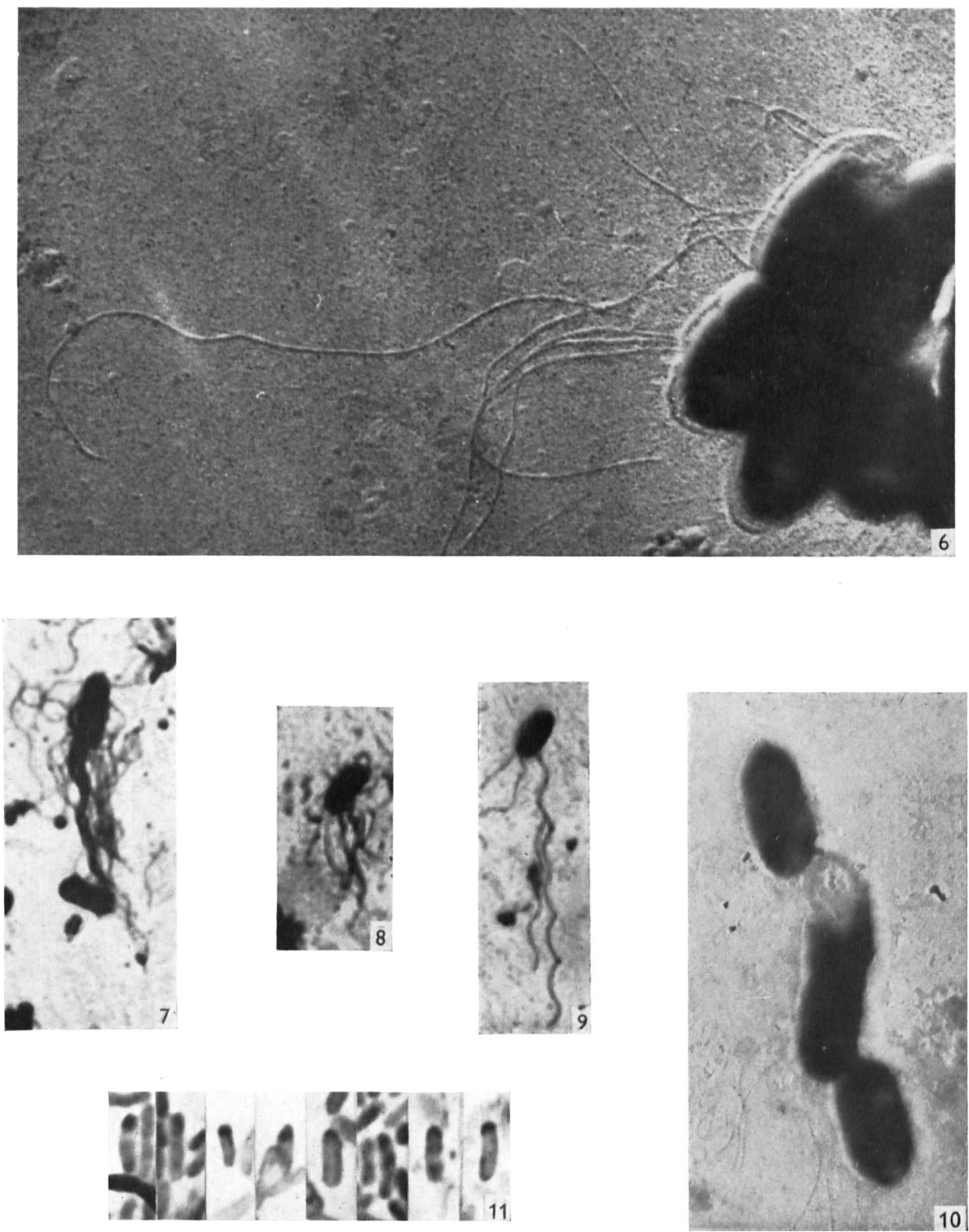

Figs. 6-11

K. A. Bisset-Surface structures in dividing bacteria. Plate 2 
Journal of General Microbiology, Vol. 5, No. 1
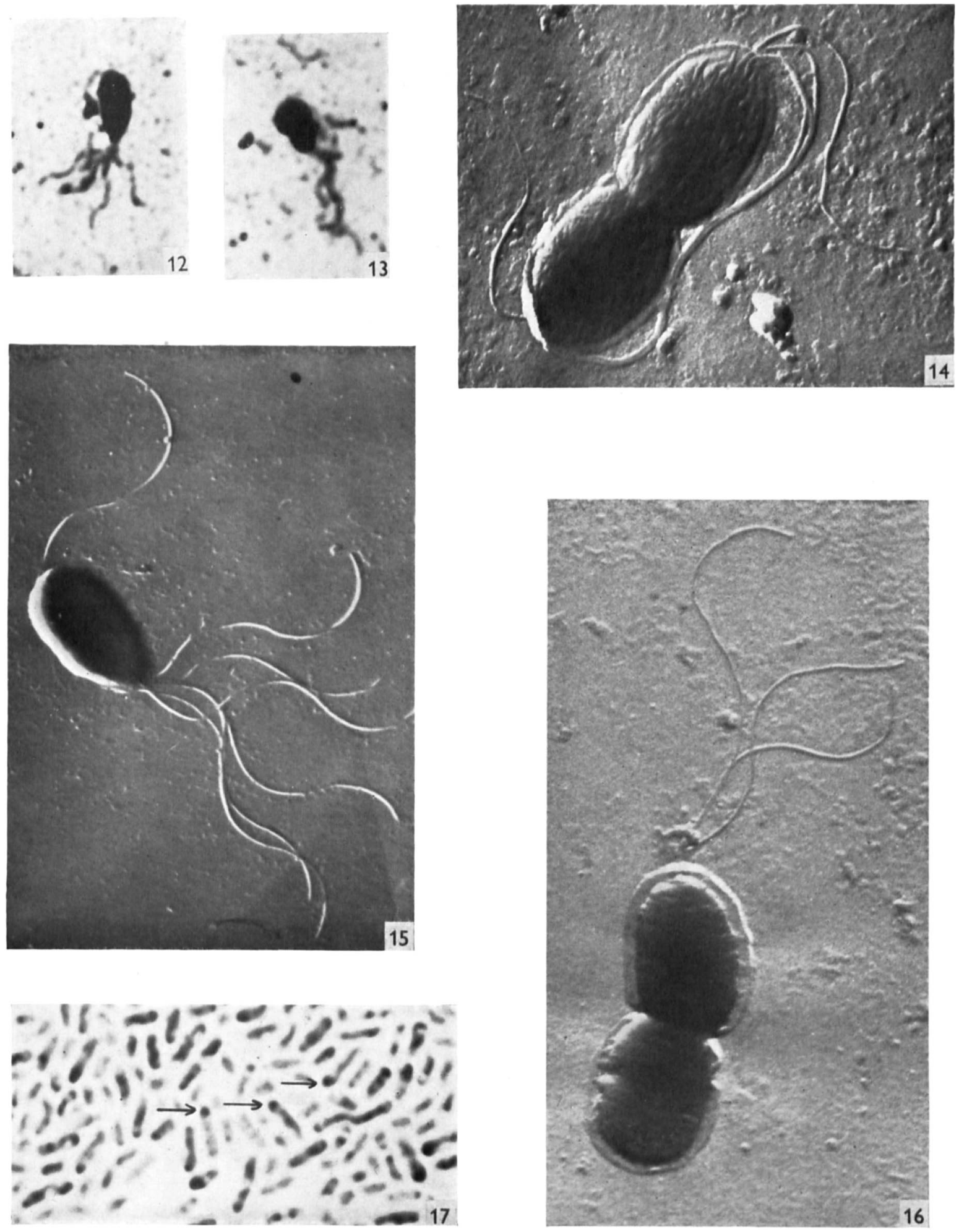

Figs. 12-17

K. A. Bisset-Surface structures in dividing bacteria. Plate 3 

nucleic acids. The growing point of the 'older' daughter cell is apparently derived from the point of division, but the 'younger' daughter cell retains the original active pole, at least in the case of Proteus, although Pseudomonas may behave in a slightly different manner, as is explained below.

The flagella behave exactly as though they were firmly attached to the cell wall, and their positions, relative to each other, remain constant as the cell enlarges. This is to say their relative distances do not increase, as they would if the whole cell wall increased in area. The new cell wall, at the growing end of the cell, does not begin to produce flagella until it has achieved a certain degree of maturity. In the case of Proteus it may do so fairly soon after its formation; in the case of Salm. typhi the non-flagellated period is much longer. The behaviour of Ps. fuorescens, in this respect, is conditioned by the polar position of the flagella, but the author's interpretation is that, most usually, the flagella do not begin to develop upon the growing tip, but do so only after elongation of the cell at this point has ceased, so that the growing tips of both cells are derived from the new point of division. This constant alteration in polarity may be reflected in the occasional production of flagella at both ends of germinating microcysts.

The behaviour of these surface structures at cell division suggests that bacteria do not divide by simple fission, but that each cell produces a bud of a size which is often, although not always, equal to that of the parent cell.

\section{REFERENCES}

Bisset, K. A. (1948). The cytology of smooth and rough variation in bacteria. J. gen. Microbiol. $2,83$.

Bisset, K. A. (1950). The Cytology and Life-History of Bacteria. Edinburgh: Livingstone.

Bisset, K. A. \& Hale, C. M. F. (1951). The development of bacterial flagella in the germinating microcyst. J. gen. Microbiol. 5, 150.

\section{EXPLANATION OF PLATES}

(The electron micrographs were made with the assistance of Miss C. M. F. Hale and Mr C. C. Newton.)

Plate 1

Figs. 1, 2. Salm. typhi. Young bacteria on the point of division. Flagella confined to one end. Electron micrograph, gold-shadowed. Fig. 1, $\times 5,500 ;$ fig. $2, \times 9,000$.

Fig. 3. As figs. 1 and 2. Silver impregnation. $\times 3,000$.

Fig. 4. Salm. typhi. Dividing cell, all flagella are confined to one daughter cell. Observe short, growing flagella at one pole and transparent growing point at the other. Electron micrograph, gold-shadowed. $\times \mathbf{7 , 0 0 0}$.

Fig. 5. Salm. typhi. Bacteria immediately after division. One daughter cell is flagellated, the other bears only rudimentary flagella. Silver impregnation. $\times 6,000$.

\section{Plate 2}

Fig. 6. Pr. vulgaris. Dividing bacterium. The growing point is clearly seen on the right, and this cell has shorter flagella than the left-hand daughter cell, which has longer flagella and no growing point. Electron micrograph, gold-shadowed. $\times 2,000$.

Figs. 7, 8. Pr. vulgaris. Bacteria growing and dividing. Long flagella upon one half of the cell, short or none on the other. Silver impregnation. $\times \mathbf{3 , 0 0 0}$. 
Fig. 9. Pr. vulgaris. Recently divided bacteria. One daughter cell has many well-developed bacteria, the other has very few, and these much shorter. Silver impregnation. $\times \mathbf{3 0 0 0}$.

Fig. 10. Pr. vulgaris. Actively growing bacterium with transparent growing point (flagella not well shown) between resting bacteria without differentiated poles. Electron micrograph, gold-shadowed. $\times 8,000$.

Fig. 11. Salm. typhi. Growing points. Aggregations of stainable material at one pole of the cell and at the point of division. Giemsa. $\times 3000$.

Plate 3

Figs. 12-15. Ps. fluorescens. Dividing bacteria with fully developed tufts of flagella at one pole and single, growing flagella at the other. Figs. 12, 13, silver impregnation, $\times 3000$; figs. 14, 15, electron micrographs, gold-shadowed, $\times 16,000$.

Fig. 16. Ps. fluorescens. Dividing bacterium with flagella at only one pole. Electron micrograph. $\times 16,000$.

Fig. 17. Ps. fluorescens. Growing points. Aggregations of stainable material at one pole of the bacterium, and at the point of division. Giemsa. $\times 3000$.

(Received 11 April 1950) 